Karadeniz Uluslararası Bilimsel Dergi

Volume: 42, Summer-2019, p. 204-222

ISSN: 1308-6200 DOI Number: 10.17498/kdeniz.520614

Research Article

Received :January 31, 2019 Accepted: May 6, 2019

This article was checked by iThenticate

\title{
GÖKHÖYÜK BAĞLARI HÖYÜĞÜNDEN ERKEN DEMİR ÇAĞI SERAMİ̆̈I
}

\author{
EARLY IRON AGE CERAMICS FROM THE GÖKHÖYÜK \\ BAĞLARI MOUND
}

\section{КЕРАМИКА РАННЕГО ЖЕЛЕЗНОГО ВОЗРАСТА ОТ ЛЮДЕЙ ГЁХЁЮКА}

\section{Ramazan GÜNDÜZ}

\section{ÖZ}

Yaklaşı olarak MÖ 1200'lerin başlarında meydana gelen büyük bir kavimler göçü, Anadolu'nun ve Yakındoğu'nun sosyal ve siyasi yapısında büyük değişimlere sebep olmuştur. Bu göçler sonrasında MÖ 2. binyılın monarşik birçok devleti (Hitit, Mitanni, III. Babil, "Kaşga") ortadan kalkmıştır. Anadolu coğrafyasındaki bu kargaşalarla birlikte yazılı kaynakların kesilmesi, burada yaşayan topluluklar hakkında kısıtlı bilgilerin ele geçmesi bu dönemin Karanlık Çağ olarak adlandırılmasına sebep olmuştur. Zaman içinde Boğazköy Hattuşa, Gordion Yassı Höyük, Alişar, gibi yerleşmelerde yapılan kazılarda açığa çıkarılan seramiklerden elde edilen bulgular Orta Anadolu Demir Çağı'nın aydınlatılmasına önemli katkılar sunmuştur. Boğazköy-Hattuşa, Gordion ve Kaman Kale Höyük'te son dönemde temiz tabakalardan çıkarılan seramikler üzerinde yapılan C14 analiz sonuçları Orta Anadolu Demir Çağı'nın daha anlaşılır bir hale gelmesini sağlamıştır. Konya Ovasında ise kapsamalı bir kazı çalışması olmadığından bölgenin Erken Demir Çağı hakkındaki bilgilerimiz yüzey araştırmalarından gelen sonuçlardan elde edilmektedir. Konya Ovası'nın güney batısında bulunan Gökhöyük Bağları Höyüğünde yapılan kazılarda ortaya çıkarılan bir grup Erken Demir Çağ seramiği bu çalışmanın konusunu oluşturmaktadır. İncelenen çanakların bir kısmı üzerinde ip baskı bezeme bulunurken kalan parçalarda herhangi bir bezeme görülmez. Burada çalışlan seramiklerden yola çıkarak Gökhöyük Bağları Höyüğün de Erken Demir Çağı'na geçişte kültürel devamlılığın devam edip etmediğinin anlaşılmasına katkı sağlamak amaçlanmıştır.

Anahtar Kelimeler: Konya, Gökhöyük, Demir Çağı, Erken Demir Çağı Seramiği, Seramik 


\section{ABSTRACT}

The great tribal migration that broke out approximately in the 1200 B.C. caused great changes in the social and political structure of Anatolia. After these migrations, many monarchical states of the 2nd Millennium BC (Hittite, Mitanni, Babylon, Kasga) disappeared. The interruption of the written sources along with the turmoil in the Anatolian geography and the information about the communities living here being very limited has caused this period called Dark Age. The new studies and the new archaeological data obtained in time made it possible to enlighten this period. The finds obtained from the ceramics unearthed in excavations in Gordion Yass1 Höyük, Boğazköy, Hattusa, Alisar, have contributed significantly to the elucidation of Central Anatolia Iron Age. The results of the C14 analysis on the ceramics recently obtained from the clean strata at Bogazköy-Hattusa, Gordion and Kaman Kale Höyük and the comparisons made with analogical methods ensured the Central Anatolian Iron Age to become more understandable. Since there is no comprehensible excavation work in the Konya Plain, the information about Iron Age of this region is obtained from the data coming from surface researches that have been going on in the area for many years. A group of Early Iron Age ceramics unearthed during the excavations at Gökhöyük Bağları Mound, which is located to the southwest of the Konya Plain, is the subject of this study. Some of the cups examined have rope print decoration on it and there is no embellishment on the remaining pieces. The aim of this study is to contribute to the understanding of the continuity of the cultural continuity in the transition from Gökhöyük Bağları to Early Iron Age.

Keywords: Konya, Gökhöyük, Iron Age, Early Iron Age Pottery, Pottery.

\section{АННОТАЦИЯ}

Миграция крупных племен, имевшая место в начале 1200-х годов около нашей эры, вызвала большие изменения в социальной и политической структуре Анатолии и Ближнего Востока. После этих миграций многие монархические государства 2-го тысячелетия до нашей эры (хетты, Митанни, Вавилон III, ик Кашга ин бин) исчезли. В связи с беспорядками в Анатолии, прекращением письменных источников и сбором ограниченной информации об общинах, живущих там, этот период был назван темным веком. Результаты, полученные из керамики, обнаруженной в ходе раскопок, проводившихся в таких поселениях, как Богазкой Хаттуша, Гордион Яссы Хойюк, Алишар, внесли важный вклад в освещение железного века Центральной Анатолии. Результаты анализа C14 на керамике, извлеченной из чистых слоев в БогазкойХаттуше, Гордионе и Камане-Кале-Хойюке, сделали железный век Центральной Анатолии более понятным. Поскольку на равнине Конья не ведутся закрытые земляные работы, наши знания о раннем железном веке региона основаны на результатах обследований. Предметом исследования является группа керамики раннего железного века, раскопанная во время раскопок в кургане Гёкхёюк-Баглары, который расположен к юго-западу от равнины Конья. Некоторые из исследованных чашек украшены орнаментом в виде веревки, а на оставшихся предметах нет украшений. Целью данного 
исследования является содействие пониманию преемственности культурной преемственности при переходе от Гёкхёюк Баглары к раннему железному веку. век, Керамика.

Ключевые слова: Конья, Гекхойюк, железный век, Ранний железный

\section{Giriş}

Yaklaşık olarak MÖ 1200'lerde meydana geldiği ileri sürülen büyük bir kavimler göçü, Anadolu'nun ve Yakındoğu'nun bu döneminin siyasi yapısında büyük değişimlere sebep olmuştur (Çilingiroğlu 1987, 108; Arslan 1998, 1). Bu göçler sonrasında MÖ 2. Binyılın monarşik birçok devleti (Hitit, Mitanni, III. Babil, ' 'Kaşga') ortadan kalkmıştır. Bunların yerine gelenler ise teşkilatsız ve kültür düzeyi II. Binyıl kültürleri kadar yüksek olmayan kavimlerin kurduğu beylikler şeklindedir (Ünal 2006, 69). Bu göçler, bazı kaynaklara göre İllyr ve Trak halkları arasındaki anlaşmazlıklar sonucunda (Götze 1933, 111 vd.) bazı kaynaklara göre ise ekonomik sebeplerden dolayı ortaya çıkmıştır (Memiş 2002, 145). Batı ve güney yönündeki bu göç dalgaları "Ege Göçleri” ya da "Deniz Kavimleri Göçü” (Akurgal 2007, 139) olarak adlandırılmıştır. Ahmet Ünal gibi bazı bilim insanları ise Hitit Devleti ve onunla birlikte daha birçok askeri gücün yıkılıp tarih sahnesinden silinmesine neden olan tarihi olayların yeterince açık olmadığını düşünmektedir. Tüm Önasya ve Yakın Doğu'ğunun yağmalanmasından, yakıp yıkılmasından Ege Göçleriyle geldikleri var sayılan ve Deniz Kavimleri denen yarı hayali bir kavmin sorumlu tutmanın gerçekleri yansıtmadığını belirtmektedir. Ünal, Hitit İmparatorluğunun yıkılmasıyla Anadolu’ya göçlerin olduğunu kabul ederken, imparatorluğun yıkılışını Deniz Kavimlerine bağlamanın doğru bir yaklaşım olmayacağını, Deniz Kavimleri göçünü destekleyen yeterli verilerin olmadığını savunmaktadır (Ünal 2006, 68-69). Bu göçler hakkındaki en kapsamlı bilgileri sunan kaynaklar ise Misır belgeleridir (Taylor 1972, 174; Umar 1982, 70). Misır annallerinde "Deniz Kavimleri" olarak adlandırılan bu kavimlerin göç hareketleri iki aşamada yaklaşık olarak M.Ö. 13. ile 12. Yüzyıl aralığında meydana geldiği bildirilmiştir. Bu göçlerden ilki Merneptah'ın hükümdarlığının beşinci yılında (M.Ö. 1207) meydana gelmiştir (Thorpe 2001, 18-19; Cline 2006, 19). Firavun Merneptah Deniz Kavimleri'ne karşı yaptığı mücadelede büyük bir zafer kazanmıştır. Bu olay Karnak Tapınağının duvarlarında yazdırılmıştır (Drews 2014, 52). Buradaki yazıta göre Firavun Merneptah tarafından mağlup edilen ve Deniz Halkları olarak da adlandırılan kavimler (Redford 1992, 246), Ekweşler (Akalar), Turşalar (Etrüskler), Rukkalar (Lukkalar), Şerdanalar (Sardunyalılar) ve Sekeleşlerdır (Sicilyalılar) (Memiş 2002, 145). Bronz Çağı'nın sonunu getiren ikinci göç dalgası ise III. Ramses'in hükümdarlığının sekizinci yılında (M.Ö. 1186) gerçekleşmiştir (Ceresko 1992, 170; Davis ve Hamilton 2006, 232-23). Bu ikinci göç hareketiyle Hititler'in durduramadıkları barbar ve saldırgan kavimlerin güzergahları üzerinde bulunan tüm uygarlık merkezlerini Hatti (Hitit), Karkamış, Kode (Kilikya), Arzava ve Alaşiya'yı (Kıbrıs) yakıp yıkarak Mısır sınırlarına dayandıkları Medinet Habu tapınağının duvarlarındaki yazıtlarda anlatılmaktadır (Cline 2006, 19-20; Kuhrt 2013, 7). Bunlar ancak III. Ramses'in 8. idare yılında (MÖ 1198-1166) yapılan büyük savaşla durdurulurlar. III. Ramses'in kazandığı bu büyük zafer, Medinet-Habu mabedinin duvarları üzerinde hem hiyeroglif yazıyla hem de resimlerle anlatılmıştır (Breasted 1948, 464-505; Kınal 1987, 227; Memiş 2002, 148). Meydana gelen bu göç 
dalgalarının sonucunda, Trako-Frig (Akurgal 2007, 136; Sevin, 2001, 16) olarak bilinen halklar, Troya'nın ele geçirilmesinden sonra Anadolu içlerine yayılırken, Kıta Yunanistan ve Ege adalarında bulunan Akalar Anadolu'nun batı ve güneybatı kıyılarına doğru göç etmişlerdir (Akurgal 1955, 113 vd.). Bu kavimler Anadolu’daki bazı yerleşik halklarla da birleşip durdurulamaz bir felakete dönüşmüşler ve Anadolu'nun içlerine yönelerek Hititler'in başkenti Hattuşa'yı yakıp yıkmışlar, iyice zayıflayan Hitit İmparatorluğu'nu, olasılıkla Kaşgalar'ın da yardımıyla, ortadan kaldırmışlardır (Breasted 1906, 64; Akurgal 1955, 113 vd.; Götze 1975, 266). Bu dönemde Orta Anadolu'da bulunan Boğazköy (Bittel 1970, 132 vd.), Alişar (Osten 1937, 289), Alaca Höyük (Koşay 1938, 179), yanında diğer Hitit yerleşmelerinde yangınla son bulmuş olduğu iddia edilmektedir. Hattuşa'da büyük saray komplekslerinin bulunduğu Büyükkale yağmalanmış, kompleks içinde bulunan bütün yapılar yerle bir edilmiştir. Bunlara ilaveten, Anadolu tarihi hakkında önemli bilgiler sunan Hitit yazılı metinlerinin birden bire kesilmesi bu yıkımın başka bir belirtisi olarak değerlendirilmiştir (Laroche 1953, 70 vd.; Götze 1975, 261). Anadolu coğrafyasındaki bu kargaşalarla birlikte yazılı kaynakların kesilmesi, burada yaşayan topluluklar hakkında kısıtlı bilgilerin ele geçmesi kronolojik tarihlemede Erken Demir Çağı olarak tanımlanan bu dönemin Karanlık Çağ olarak adlandırılmasına sebep olmuştur (Arslan 1998, 14). Zaman içinde yapılan yeni çalışmalarla ve elde edilen yeni arkeolojik veriler bu dönemin aydınlanmasına olanak sağlamıştır. Bizde, burada özellikle Orta Anadolu Platosu'nun güney batısında bulunan Gökhöyük Bağları Höyüğü'nde Konya Müzeler Müdürlüğü tarafından 2002 - 2005 yılları arasında yürütülen kurtarma kazılarında açığa çıkarılan Erken Demir Çağ seramikleri yardımıyla bu döneme 1şık tutmaya çalışacağız. Ancak burada konu bütünlüğünün oluşabilmesi için kısaca genel olarak Orta Anadolu Erken Demir Çağı çalışmalarına değinmek yerinde olacaktır.

\section{Erken Demir Çağı}

Hali hazırda kullanılan kronolojik sıralamaya göre Hitit İmparatorluk Çağı'nın sona ermesi ile Tunç Çağlarının da son bulduğu ve bunun ardından da Demir Çağının başladığı kabul edilmektedir (Kealhofer ve Grave 2011, 415; Matsumura 2001, 102). İmparatorluğun yıkılmasıyla siyasi düzen bozulmuş birçok yeni beylik ortaya çıkmış ve bu döneme kadar devam eden yazılı kaynaklar susmuştur (Ünal 2006, 69). Bununla birlikte Hitit İmparatorluk döneminde Anadolu'nun tamamında kültürel bir bütünlüğün varlığından söz edilirken, Erken Demir Çağı'na gelindiğinde Hitit coğrafyasının kendi içinde küçük kültürel bölgelere bölünmüş olduğu görülmektedir (Matsumura 2005. 506). Kımıyoshı Matsumura Erken Demir Çağı Kültürlerini değerlendirirken, Orta Anadolu sınırları içerisinde Büyükkaya'da ve Gordion'da olmak üzere iki farklı Erken Demir Çağı çanak çömlek kültürünün varlığından bahsetmektedir ${ }^{1}$. Bununla birlikte 19 . ve 20. yüzyılda yapılan çalışmalardan elde edilen veriler incelendiğinde Anadolu coğrafyasında Demir Çağı için genel geçer bir kronolojik tablonun da oluşturulamadığı görülmektedir (Genz 2011, 334). Ancak

\footnotetext{
${ }^{1}$ Matsumura İç Anadolu dışında ise üç tane daha, Troja VIIb'den bilinen (Knobbed Ware) Yumurcuklu mallar ve Doğu Anadolu'dan bilinen (Grooved Ware) Yivli Mallar son olarak da Kilise Tepe'de, Tarsus ve Kinet Höyük'den bilinen kırmızı boyalı seramik (redpainted pottery culture) Erken Demir Çağı veya geçici seramik kültürü olduğundan bahseder bkz. Matsumura 208, 42-43.
} 
dönemin başlangıcının, Erken Demir Çağı'nın, Boğazköy'de Hitit İmparatorluğu'nun sonuna doğru, yani MÖ 1200'den kısa bir süre sonra başladığı kabul edilir (Genz 2004, 36). Her ne kadar bu dönem için mutlak tarihler çok az mevcut olsa da, hali hazırda oluşturulan kronolojiye göre Demir Çağı için Erken, Orta ve Geç Demir Çağı terimleri kullanılmaktadır (Genz 2011, 335). Demir Çağı kronolojisini oluşturmak için kullanılan mutlak kronolojik veriler sınırlı olduğu kadar da tartışmalıdır. Bu bölge içinde herkes tarafindan kabul gören en kesin veriler Kaman-Kalehöyük (Omura 1996, 93; 2000, 32), Boğazköy (Seeher 1997, 327-331), Gordion (Genz 2004, 7-10; Voigt 1994, 267-68) ve Çadır Höyük'ten (Kealhofer vd. 2010, 71-92) gelmektedir. Yapılan bir dizi radyokarbon tarihi, MÖ 12. ve 10. yüzyıl aralığının kendi içinde safhalara ayrılan Erken Demir Çağı safhalarının tamamını yansıttığı anlaşılmaktadır (Seeher 2000, 373). Boğazköy Büyükkaya'da açığa çıkarılan mimari tabakalar içinde Erken Demir Çağı'na tarihlenen seramikler bulunmuştur. Bu seramikler mimariye paralel olarak Erken, Orta ve Geç olmak üzere üç safhada değerlendirilmiştir. KamanKalehöyük ve Boğazköyden elde edilen C14 analiz sonuçları Erken Demir Çağı'nın, erken evre MÖ 1180-1125, orta evre MÖ 1125-1065 ve geç evre MÖ 1070-990 olarak üç alt evreye ayrılabileceğini göstermiştir (Genz vd. 2006, 68; Seeher vd. 1999, 337339). Bununla birlikte Orta Anadolu Erken Demir Çağı çanak-çömlek geleneği tam olarak aydınlatılamamıştır. Bunun sebebi olarak da Hitit İmparatorluk döneminde Anadolu'da bütünlük gösteren bir seramik kültürünün varlığından söz edilirken, Erken Demir Çağı'na gelince Hitit coğrafyasının kendi içinde küçük ayrı seramik bölgelerine bölünmüş olması gösterilmektedir (Matsumura 2005, 506). Örneğin Kızılırmak kavisi içine kalan bölgede Boğazköy-Büyükkaya, Alaca Höyük, Eskiyapar ve Çadır Höyük, gibi yerleşmelerde kırmızı boyalı çanak çömleğin yaygın olarak kullanıldığ düşünülmüştür (Genz 2000, 111). Kızılırmak'ın batısında kalan bölgede yani Gordion ve Kaman-Kalehöyük gibi yerleşmelerde ele geçen Erken Demir Çağı çanak-çömleği içinde de el yapımı mallar (Voigt ve Henrickson 2000, 44) bulunurken çark yapımı seramikler ağırlıktadır.

\section{Gökhöyük Bağları Höyüğü Konumu ve Araştırma Tarihi}

Konya Müzeler Müdürlüğü tarafından 2002 - 2005 yılları arasında kurtarma kazıları yapılan Gökhöyük Bağları Höyüğü, Konya ili, Seydişehir ilçesi Gökhöyük ve Kesecik sınırları içinde kalmaktadır (Gündüz 2016, 44). Höyük tam olarak Konya Antalya Karayolunun Seydişehir ilçesi girişinden ayrılan ve SeydişehirdenGökhöyük/ Ortakaraviran/ Akkise/ Bozkır'a ulaşımı sağlayan yolun 10.kilometresindeki Gökhöyük köyünden, Kuran Köyü’ne doğru giden stabilize yolun 3. kilometresinde bulunan Kuran köprüsünün yaklaşık 400 metre kadar kuzeyinde bulunmaktadır. Söz konusu höyük 1/25 000 ölçekli Konya N 27.b2 pafta numaralı haritada; 4142900, 4143100, kuzey-güney 407500, 407700 doğu-batı koordinatları içerisinde kalır. (Harita 1). Belirtilen koordinatlar içinde yer alan höyüğün 407600, 407700 doğu-batı 4142800, 4143100 kuzey-güney koordinatlarını kapsayan kısımda ilk kazı çalışmaları gerçekleşmiştir. Höyügün keşfine sebep de tam da yukarıda verilen koordinatlardan Devlet Su İşleri 4. Bölge Müdürlüğü tarafından KOP kapsamında Çarşamba çayı ile birlikte Çumra Ovasında Sulu tarımın yapılabilmesine katkı sağlamak amacıyla açılan bir kanal kazısıdır. (bu kanal Osmanlı döneminde (Değerli 2014, 319-336) burada açılan ilk toprak kanalın yerine daha büyük ve daha çok su taşıma kapasitesine sahip olacak yeni betondan yapılacak bir kanal olarak planlanmıştır) Beyşehir gölünün suyunun Çumra ovasına taşınması 
kapsamında yapılan kanal kazısının höyügüun doğu kıyısından geçmesiyle ortaya çıkan eserlerin fark edilerek Konya Müzeler Müdürlüğü’ne bildirilmesiyle höyük tespit edilmiştir (Gündüz 2016, 44). Bunu takiben 1. derece sit kapsamına alınan Gökhöyük Bağları Höyüğü'nde kazı çalışmaları Müze Müdürlüğü başkanlığında yapılmıştır (Gündüz 2018, 25). Bu kanal açma çalışmasında höyüğün güneydoğusunda, kuzey güney doğrultusunda bir tahribat oluşmuştur. Müze Müdürlüğünce höyükte görevlendirilen Arkeolog Sanat Tarihçi Muammer KOYUNCU, Arkeolog Enver AKGÜN ve Gülseren KARAKAP denetiminde bu tahribat görmüş alanlarda ilk çalışmalar 24.09.2002 tarihinde başlamıştır. Höyükte ilk olarak topografik haritalandırılma yapılmıştır. Bu haritalama üzerinde A noktasından $\mathrm{G}$ noktasına kadar olan alanın plan kare planlaması yapılmıştır. Buradan alınan ölçümler referans alınarak kanal çalışması içerisinde kalan alan 10X10 ebatında karolajlara bölünmüştür. Bu plan karelemeyle oluşturulan ilk kazı açmaları höyügüun 1.5 metre kadar derinlikte tahrip edilerek toprağının bir kısmının alındığı 13,14,15,16/D, E,F, 17/D,E, 18/E,F, numaralı alanlarda oluşturulmuştur. Proje başlangıcından sonuçlanana denk D plan karesi ile G plan karesi arasında kazılar yapılmıştır. Höyükte yapılan ölçümlere göre en yüksek kot 13/D plan karesinin bulunduğu alanda 1109.84 metre olarak ölçülmüş, tahribatın gerçekleştiği alanlardan 13/E'nin kotu $1108.72 \mathrm{~m}$., 14D'nin 1109.49m., 14/E'nin 1106.06m., 15/D'nin 1107.78 m., 15/E'nin 1105.73m., 16/D’nin 1107.82 m., 16/E'nin 1105.49 m., 17/D’nin 1106.59 m., 17/E'nin 1105.08 $\mathrm{m}$. olduğu görülmüştür. Buda bize höyük üzerinde yaklaşık olarak $50 \mathrm{~m}$. uzunluğunda 12-15 m. genişliğinde ve 0-1.5 m. derinliğinde bir tahribatın yapıldığını göstermektedir². (Resim 1) Yapılan çalışmalarda Höyüğün geç dönemde (islami Dönem) mezarlık alanı olarak kullanılmasından en üst katmanda bulunan Demir Çağı yerleşmelerine ait mimari yapılar ağır tahribat görmüş̧ür. Açığa çıkarılan mezarların etrafının taşlarla çevrili olması, burada mezar çukurları kazılırken Demir Çağı yapılarının duvarlarının sökülerek bu mezarlarda tekrar kullanıldığını akla getirmektedir (Resim 2). Bu mezarların çevresinden ve içinde bulunduğu mimari yapılardan çok sayıda kaba koyu yüzlü Demir Çağı seramiği ele geçmiştir.

\section{Gökhöyük Bağları Höyüğü Erken Demir Çağı Seramiği}

Bilindiği üzere ana maddesi kil olan pişmiş toprak kaplar kolayca kırılabilir, ama bu kaba ait parçalar doğada kendiliğinden yok olmaz. Bunlar tek tek parçalar olarak herhangi bir şekilde ikincil kullanımları olmadığı için kazılarla yeniden ele geçinceye kadar atıl vaziyette durular. Buna karşın demirden, bronzdan ve ya diğer kıymetli metallerden üretilmiş eşyalar eritilerek tekrar kullanılırlar. Bunların dışında kalan mermerden üretilmiş eserler ise genelde kireç ocaklarında ham madde olarak kullanılmışlardır. Gökhöyük Bağları Höyüğünde yapılan çalışmalarda da çok sayıda Demir Çağı'na tarihlenen çanak-çömlek parçası açığa çıkarılmıştır. Yapılan incelemeler ve bölgesel kıyaslamalara göre tasnif edilen bir grup çanağın Erken Demir Çağı özellikleri yansıttığı anlaşılmıştır. Büyükkaya'da ele geçen Erken Demir Çağı seramiklerin büyük bir bölümü el yapımıyken \%30 civarında çark üretimi çanak çömlek tespit edilmiştir (Genz 2004, 24). Hermann Genz, Erken Demir Çağın erken

\footnotetext{
${ }^{2}$ Burada verilen kazı çalışmalarına ait bilgiler Ark. San. Tar. Muammer Koyuncu,
} Ark. Enver Akgün ve Gülseren Karakap tarafından hazırlanan ve Müze Müdürlüğüne sunulan Gökhöyük Bağları Höyüğü 2002 Yılı Kurtarma Kazısı Sonuç Raporundan faydalanılarak elde edilmiştir. 
dönemine ait çanak-çömlek buluntularını genelde, kaseler, boyunsuz kaplar, dışa dönük dudaklı çanaklar gibi basit formlardan oluştuğunu bildirmektedir (Genz 2004, 24). Genz Büyükkale çanak-çömlek seramik repartuarının Hitit dönemi seramik repartuarı ile benzerliklerine dikkat çekmektedir. Ancak Erken Demir Çağında görülen boya bezeme ve astar gibi yüzey özellikleri Hitit imparatorluk dönemi geleneğinden farklıdır (Genz 2004, 26). Mora ve d' Alfonso' ya göre de Geç Tunç Çağı üretimi kapların Erken Demir Çağı'nda de kısa bir dönem varlığını devam ettirmiştir (Mora ve d' Alfonso 2012, 388). Bura incelenen Gökhöyük Bağları Höyüğü Erken Demir Çağı seramiklerinin tamamı çark üretimidir. Ancak bunlardan bir kısmında MÖ 2.binde görülen ip baskı bezeme (Çizim 1-6) bulunmaktadır.

\section{1. Çanaklar}

Seramik çalışmalarında kullanılan literatürde açık formlar arasında değerlendirilen kaplar ağız çapının yüksekliğe olan oranına göre farklı isimlerle tanımlanmaktadırlar (Ökse 2012, 88). Burada bahsi geçen ve çanak olarak adlandırılan kaplar çapı yüksekliğinin yaklaşık iki katı kadar veya iki katından fazla olan bütün örnekleri kapsamaktadır. Servis kabı olarak da adlandırılan günlük kullanıma yönelik üretilmiş olduğu düşünülen bu tür kapların katı veya sıvı gıdalar konulmak için üretilmiş olduğu tahmin edilmektedir. Kendi içinde üç ayrı tipe ayrılan toplamda 12 adet çanak bu çalışmada incelenmiştir. İncelenen kaplar üretim tekniği açısından ele alındığında tamamı çarka üretilmiş olup çark izleri kısmen gözle görülebilmektedir. Çanakların tamamı kalın cidarlı kaba seramiklerdir. Form özellikleri ise kısmen sağlam olan örneklerden yola çıkarak, çanakların içe doğru kalınlaştırılmış ağız kenarlı, ağızdan kaideye doğru daralan konik gövdeli ve halka kaideli bir forma sahip oldukları anlaşılmaktadır(Çizim 1-12). Bu form kendi içinde ağız kenarlarının kalınlaştırılmalarına göre; Tip 1, yuvarlatılarak içe kalınlaştırılmış ağız kenarlılar (Çizim 1-6), Tip 2, hem içe hem dışa doğru kalınlaştırılmış ağız kenarlılar, T biçimliler olarak da adlandırılırlar (Çizim 7-9) ve içe doğru dik kalınlaştırılmış ağız kenarlılar olarak alt tiplere ayrılmaktadır. Hamurlarına bakıldığında kilin iyi arıtılmamış olduğu görülen iri taşçık katkılardan anlaşılmaktadır. Bunun dışında çok az oranda organik katkı yanında kuvars, kalker (kireç) ve altın mika'nın katkı olarak kullanıldığı görülmektedir. Yüzey özelliklerine göre değerlendirecek olursak, Tip1 içinde değerlendirilen 6 çanak üzerinde astar uygulaması vardır (Çizim 1-6). Kalın astar olarak nitelendirebilecek bu astar'ın bir fırça ile sürüldüğü seramik üzerindeki izlerden anlaşılmaktadır. Bunlardan dördünün soluk kımızı renkli astar ile kaplıyken kalan iki tanesi koyu yüzlü gri astarlıdır. Tip 2 ve Tip 3 içinde değerlendirilen 6 parçanın ise kendinden astarlı oldukları anlaşılmaktadır. Bu parçalardan bazılarının parlak yüzeyli olması (Çizim7 ve 12) yumuşak açkı uygulaması olduğunu işaret etmektedir. Çanakların yüzeylerinin genelinde mat bir görünüşün olması ise yapılan sert açkıdan kaynaklanmış olmalıdır. Çanakların Dış ve İç yüzey renkleri çoğunlukla aynı olmakla birlikte bazı örneklerin dış yüzeylerinde tahminen firınlamadan kaynaklı alacalanmalar söz konusudur. Yüzey özelliklerine göre koyu yüzlü gri veya siyah astarlı olanlar ile soluk kırmızı veya kahverengimsi kırmızı astara sahip olanlar olarak kabaca iki guruba ayırılmıştır. Söz konusu kapların hiçbirinde boya bezeme bulunmazken, Tip 1 içindeki 6 parça üzerinde kabın dışında, ağız kısmının hemen altında bulunan ip baskı bezek bazı örneklerde tek sıra olarak bazılarında ise iki ve üç sıra halinde görülmektedir. Bu çanakların benzer örnekleri Yazılıkaya (Bittel vd. 1941, Abb 71, 17-23), Kaman- 
Kalehöyük (Matsumura 2015 Taf.14-19 KL95-M446), Gordion (Gunter 1991, Fig. 12-17), Porsuk (Dupre 1983, Pl. 77. Niveau III), Kınık Höyük'de (Ergürer 2015, Lev. 18, 153, Lev. 19, 156, 161) ve Hasan Bahar (Bahar 1999, Lev. XL, No. 1-5) ile Özdemir Koçak tarafından Konya ve çevresinde yapılan yüzey araştırmalarında (Bahar ve Koçak 2004, Çiz. 34, No.1-4, Çiz. 35, No. 2-3), Güngör Karauğuz'un yaptığ 1 çalışmalarda yine Konya ve çevre illerde Semih Güneri ve ekibinin yaptığ 1 yüzey araştırmalarında (Karauğuz 2005, Lev. 9, 2-4, 7-8), Omura ile ekibinin Kırşehir ve çevresinde yaptıkları yüzey araştırmalarında karşımıza çıkmaktadır.

\section{Değerlendirme ve Sonuç}

Son dönemde yapılan arkeolojik çalışmalarda bu döneme 1 şı tutacak bazı sonuçlar elde edilmiştir. Bu sonuçlara göre Erken Demir çağında üretilen çanakçömleğin kısmen de olsa Hitit geleneklerini devam ettirdiği düşünülmektedir ${ }^{3}$. Özellikle MÖ 1. Bin çanak çömlek geleneğine bakıldığı zaman Hitit seramikleri ile benzerliklerin olduğu görülebilmektedir (Henrickson 1994, 106; Müller ve Karpe 1988, 24-146). Bu tespitlerden ortaya çıkan sonuç ise, Orta Anadolu'da bulunan yerleşmelerin Hitit İmparatorluğu'nun yıkılmasından sonraki süreçte daha önce söz edildiği gibi tamamen terk edilip karanlığa bürünmediği, kısıtlıda olsa buralarda kültürel yaşamın devam ettiği gerçeğidir.

Gökhöyük Bağları Höyüğünde yapılan kazılarda da bu dönemin aydınlatılmasına katkı sunabilecek bazı çanak-çömlek parçaları açığa çıkarılmıştır. MÖ 13.-11. yüzyıllar aralığına tarihlediğimiz bu çanakların MÖ 13.- 11.yüzyıl aralığına tarihlenmesinde diğer Erken Demir çağı yerleşmelerinde ve Geç Tunç Çağına tarihlenen yerleşmelerde bulunan benzerleri yol gösterici olmuştur. Özellikle Erken Demir Çağı Seramiklerinin bulunduğu Boğazköy ve Kaman-Kalehöyük'den elde edilen C14 sonuçlarından yola çıkarak (Genz vd. 2006, 68) bu çanakların da Erken Demir Çağının Erken safhasına tarihlenebileceği anlaşılmaktadır. Bu sonuç da Gökhöyük Bağları Höyüğü'nde sınırlı bir alanda yapılan kazılarda açığa çıkarılan çanaklar yukarıda bahsettiğimiz Erken Demir Çağında Orta Anadolu'nun tamamen terkedilmediği tezini desteklemektedir. Dolayısıyla Gökhöyük Bağları Höyügü’nde Geç Tunç Çağı'ndan Erken Demir Çağı'na geçişte herhangi bir kesinti olmadığını söylemek doğru olacaktır. Bu sonuçtan da Hitit İmparatorluğu'nun yıkılmasıyla Anadolu'daki yerleşmelerin terk edildiği düşüncesinin, en azından Orta Anadolu'nun Güneybatısı için, gerçeği yansıtmadığı anlaşılmaktadır.

Ele geçen örneklerden yola çıkarak bu kapların, açık kaplar olarak değerlendirilebilecek geniş ağızlı, içe çekik dudaklı, ağızdan kaideye doğru daralan konik bir gövdeye sahip oldukları ve bunların üzerinde herhangi bir kulp bulunmadığı tespit edilmiştir. Kalın cidarlı, kaba, çarkta şekillendirilmiş bu çanaklar büyük ihtimalle servis kabı olarak kullanılmış olmalıdırlar. Özellikle bu kaplardan ( Tip 2 ağız kısımlarının hemen altında bulunan oluğun yalnız bir bezeme değil kabı taşımak içinde kullanılmış olması gerekir. Ayrıca kapların açık yayvan ağızlı oluşu onları bir saklama kabı olmaktan çıkarmaktadır. Bunlarla mutfakta herhangi bir şey pişirilmediği de düşünüldüğünde bunların yemeklerde servis kabı olmaları gerekmektedir. Bu durum ise bu kadar büyük servis kaplarının tam olarak nasıl bir

${ }^{3}$ Jürgen Seeher Erken Demir Çağı'nda Büyükkaya sakinlerinin Erken ve Orta Tunç Çağı'na dayanan eski bir Anadolu kültürünü yaşattıklarını savunmaktadır bkz. Seeher 2000, 22. 
yiyecek için kullanıldıkları sorusunu akla getirmektedir. İçe çekik ağızlı olmalarından yola çıkarak olasılıkla içinde sulu bir yemeğin servis edildiği ve bunun dökülmemesi içinde ağızlarının içe doğru çekik dudaklı üretilmiş olmaları gerekir. Kapların boyut olarak büyüklüklerinden yola çıkarak bu servis kaplarının tek kişilik değil birçok kişinin beraber aynı anda kullanımına yönelik üretilmiş olabileceklerini düşündürmüştür. Bu da akla Demir Çağında Gökhöyük de yaşayanların kalabalık bir nüfusa sahip olduğunu akla getirir. Ancak bu konu hakkında kesin yargılarda bulunmak ayrıntılı kazılar yapılmadan maalesef mümkün olmayacaktır.

\section{BİBLIYYOGRAFYA}

Akurgal, E. ( 1955). Phrygische Kunst, Ankara.

Akurgal, E. (2007). Anadolu Uygarlıkları, 9.Bs., İstanbul: Net Turistik A.Ş.

Arslan N. (1998). Kilikya Bölgesi Demir Çağı Seramiği.(Yayınlamamış Doktora Tezi) Selçuk Üniversitesi Sosyal Bilimler Enstitüsü, Konya.

Bahar H. (1999). Demir Çă̆ında Konya Ve Çevresi, Konya.

Bahar, H., Koçak, Ö. (2004). Eskiçă̆ Konya Araştırmaları 2 (Neolitik Çăg'dan Roma Dönemi Sonuna Kadar), Konya.

Bittel, K., Naumann, R., Otto, H., (1941). Yazılıkaya, 1941 Leipzig.

Bittel, K. (1970). Hattusha, The Capital Of The Hittites, New York: Oxford.

Boardman J. (1988). The Greeks Overseas, London, 1988.

Breasted, J.H. (1948). A History, Of Egypt, London.

Ceresko, A. R. (1992). The Old Testament: A Liberation Perspective, St Pauls Byb, New York.

Cline, E. H. (2006). Archaeology And The Iliad: The Trojan War In Homer And History, Recorded Books

Çilingiroğlu, A. (1987). 24-27 Nisan 1984 Tarihleri Arasında İzmir'de Yapılan I. Anadolu Demir Çağları Sempozyumu'na Sunulan Bildiriler, İzmir, 1987. Ege Üniversitesi Edebiyat Fakültesi Yayını.

Davis, P. K. Ve Hamilton, A. L. (2006). Encyclopedia Of Warrior Peoples And Fighting Groups, Grey House Publishing.

Değerli, A. (2014). Osmanlı Dönemi'nde Suğla Gölü’nü Islah Çalışmaları Ve Suğla Mukataası, Tarih Okulu Dergisi (Tod), Y11 7, Sayı Xv111, 319-336.

Dupre, S. (1983). Porsuk I. La Ceramique D I'age Du Bronze Et De L'age Du Fer, Editions Recherche Sur Le Civilisations, Memoir No. 20, Paris.

Ergürer, H.(2016).Niğde Kınık Höyük Demir Çağı Seramikleri. (Yayınlanmamış Doktora Tezi) T.C. Atatürk Üniversitesi Sosyal Bilimler Enstitüsü Klasik Arkeoloji Anabilim Dali.

Genz, H. (2004). Büyükkaya: I. Die Keramik Der Eisenzeit, Deutsches Achaologisches Institut, By, Verlag Philipp Von Zabern, Mainz Am Rhein.

Genz, H. (2011). "The Iron Age In Central Anatolia”, The Black Sea, Greece, Anatolia And Europe İn The First Millennium Bc. Ed. Gocha R. Tsetskhladze. Leuven - Paris - Walpole, Ma. Pp. 331-368.

Götze, A. (1933). Kulturgeshichte Den Alten Orients “Kleinasien”, Handbuch Der Altertmwissenschaft I11. 1, Munich.

Götze, A. (1975). “The Hittites And Syria”, Cambridge Ancient History Il/2, 266 Vd. 
Gunter, A. C. (1991). Gordion Excavations Final Reports In "The Bronze Age", The University Museum Of Archaeology And Anthropology University Of Pennsylvania Philadelphia.

Gündüz, R. (2016). “Neolitikten Kalkolitik Döneme Kadar Bozkır Ve Çevresindeki Yerleşmeler’' Geçmişten Günümüze Bozkır Sempozyum Kitabı. Konya. 33-48.

Gündüz, R. (2018). “Gökhöyük Bağları Höyüğünden Bir Grup Demir Çağ1 Seramiği”, Uluslararası Antropoloji Arkeoloji Sanat Tarihi Sempozyumu Bildiri Özeti Kitabı. Çorum, 25.

Güneri, S. (1986). “'Orta Anadolu Höyükleri 1986” Iv. Araştırma Sonuçları Toplantısi. 205 -225, Ankara.

Karauğuz, G. (2005). Arkeolojik Ve Filolojik Belgeler Işı̆̆ııda Mö. It. Binde Orta Anadolunun Güney Kesmi, Konya.

Kealhofer, L., Grave, P., Marsh, B., Steadman, S., Gorny, R. L., Summers. G. D. (2010). Patterns Of Iron Age İnteraction İn Central Anatolia:Three Sites İn Yozgat Province. Geoffrey Anatolian Studies 60, 71-92.

Kealhofer, L. Grave, P. (2011). “Chronology And Geography”, The Iron Age On The Central Anatolian Plateau, Steadman Chapter 18, Publisher: Oxford University Press, 415-442.

Kuhrt, A. (2013). Eskiçăg'da Yakındoğu, Cilt I, Çev.: Dilek Şendil, Türkiye İş Bankası Kültür Yayınları, İstanbul.

Koşay, H.Z. (1938). Alacahöyük Hafriyatı, Ankara, Laroche, E. (1953). "Suppiluliuma I1", Revue Darcheologie Oriental, Paris, 47, 70.

Matsumura, K. (2005). Die Eisenzeitliche Keramik In Zentralanatolien Aufgrund Der Grundlage Der Von Kaman-Kalehöyük, Berlin: Inaugural-Dissertation Zur Erlangung Des Doktorgrades Am Fachbereich Geschichts Und Kulturwissenschaften Der Freien --Universitatversitat, Memiş, E. (2002). Eskiçă̆ Türkiye Tarihi, Konya.

Mora C., D’alfonso L. (2012). “Anatolia After The End Of Hittite Empire. New Evidence From Southern Cappadocia”, Origini Xxxıv. Preistoria E Protostoria Delle Civiltàn Antiche, Ed. Gangemi, Sapienza Universita Di Roma, 385-398.

Omura, S. (1996). A Preliminary Report On The Ninth Excavations At KamanKalehöyük İn Turkey (1994), Bmeccj Ix, 87-134

Omura, S. (2000). “1999 Yııı Kaman-Kalehöyük Kazıları” , 22. Kazı Sonuçları Toplantısı, Ankara: Kültür Bakanlığı Milli Kütüphane Basımevi, C. 1, Ss. 327-336.

Osten, H. H. Von Der. (1937). The Alishar Hüyük Seasons Of 1930- 1932, Part I-I11, (Oıp Xxv111-Xxx), Volume Xxx, By. J. A. Wilson, T. G. Allen, Chicago: The Üniversity Of Chicago Oriental İnstitute Publications.

Ökse, A.T. (2012). Önasya Arkeolojisinde Çanak Çömlek-Teknik Özellikler, Biçimler-Türkçe, Ingilizce, Almanca Ve Fransızca Terimler, Arkeoloji Ve Sanat Yayınları, İstanbul.

Özgünel, A. C. (2013). Anadolu'da Miken Seramiği. (Sağlam Korunmuş Kaplar Üzerine Bir Araştırma). Haz.: Canan Özbil. Anatolia Supplements I1. 1: Monogra. Ankara.

Redford, D. B. (1992). Egypt, Canaan, And Israel In Ancient Times, Princeton University Press, 246.

Seeher, J. (1997). “Die Ausgrabungen İn Boğazköy-Hattuša 1996”, Aa 1997, 317341. 
Seeher J. (2000). “Die Ausgrabungen İn Boğazköy-Hattuša 1999” Aa, Heft 3, 2000, 372-374, Abb.21, Abb.22.

Taylor, W. (1972). The Mycenaeans, Londra.

Umar, B. (1982). Türkiye Halkının İlkçă̆ Tarihi, İzmir.

Ünal, A. (2006) “'Hitit İmparatorluğu'nun Yıkılışından Bizans Dönemi’nin Sonuna Kadar Adana Ve Çukurova Tarihi’’, Ç.Ü Sosyal Bilimler Enstitüsü Dergisi, Cilt 15, Say1 3. S.67-102

\section{KATALOG}

\begin{tabular}{|c|c|c|c|c|c|c|c|c|}
\hline \multirow{2}{*}{1} & $\begin{array}{l}\text { GHB Buluntu } \\
\text { No. }\end{array}$ & $\begin{array}{l}\text { Ma } \\
\text { l }\end{array}$ & Form & $\begin{array}{l}\text { Bezem } \\
\text { e }\end{array}$ & $\begin{array}{l}\text { Hamu } \\
\mathrm{r} \\
\text { Rengi }\end{array}$ & $\begin{array}{l}\text { Astar } \\
\text { Reng } \\
\text { i }\end{array}$ & $\begin{array}{l}\text { İç } \\
\text { Ren } \\
\text { k }\end{array}$ & $\begin{array}{l}\text { A.Ça } \\
\text { p }\end{array}$ \\
\hline & $\begin{array}{l}\text { 19E/K39/T1/24 } \\
3\end{array}$ & İyi & $\begin{array}{l}\text { Çana } \\
\mathrm{k}\end{array}$ & İp bask1 & $\begin{array}{ll}2.5 & Y \\
4 / 3 & \end{array}$ & $\begin{array}{l}10 \\
\mathrm{YR} \\
6 / 3\end{array}$ & & $\begin{array}{l}18.4 \\
\mathrm{~cm}\end{array}$ \\
\hline \multicolumn{2}{|c|}{ Tanım } & \multicolumn{7}{|c|}{$\begin{array}{l}\text { Ağız kenarı-gövde parçasıdır. Yuvarlatılmış kalın dudaklı, } \\
\text { iç bükey profilli, düzleştirilmiş yüzeylidir. Koyu yüzlü } \\
\text { kabın dışında ağzın hemen altında iki sıra ip baskı bezeme } \\
\text { görülür. İyi pişmiş kabın hamuru kireç, gümüş mika ve taş } \\
\text { katkılıdır. }\end{array}$} \\
\hline & $\begin{array}{l}\text { ferans-Dönem } \\
\text { Ö 13.-11. yüzyıl) }\end{array}$ & \multicolumn{7}{|c|}{$\begin{array}{l}\text { Bittel - Naumann - Otto 1941, Abb. } 70 \text { 8a-8b, } \\
\text { 10,12,13,15, Abb 71, 2-4 (Bau-B MÖ 14.-13. yüzy1l); } \\
\text { Bouthillier 2014, Lev. 46, No. C, D, F, Fig. } 48 \text { (Geç Bronz } \\
\text { Çağ1); Güneri 1987, Res. 4, No. 8-11, 20-22, Res. No.11,13 } \\
\text { (Son Bronz Çağ1); Karauğuz 2005, Lev. 9, 2-4,7-8 (MÖ } \\
\text { 2.bin); Bahar - Koçak 2004, çiz. 34 no.1-4, Çiz. 35, No. 2- } \\
\text { 3: Bahar 1999, Lev. XL,No. 1-5 (Erken Demir Çağ) }\end{array}$} \\
\hline
\end{tabular}




\begin{tabular}{|c|c|c|c|c|c|c|c|}
\hline Buluntu & Mal & Form & Bezeme & $\begin{array}{l}\text { Hamur } \\
\text { Rengi }\end{array}$ & $\begin{array}{l}\text { Astar } \\
\text { Rengi }\end{array}$ & $\begin{array}{l}\text { İç } \\
\text { Renk }\end{array}$ & A.Çap \\
\hline 17G/K42/T1/201 & Kaba & Çanak & & $\begin{array}{ll}2.5 & Y \\
5 / 2 & \end{array}$ & $\begin{array}{l}7.5 \\
\text { YR } \\
4 / 1\end{array}$ & & $\begin{array}{l}32.2 \\
\mathrm{~cm}\end{array}$ \\
\hline Tanım & \multicolumn{7}{|c|}{$\begin{array}{l}\text { Ağı kenarı-gövde parçasıdır. Yuvarlatılmış kalın dudaklı, iç } \\
\text { bükey profilli, düzleştirilmiş yüzeylidir. Koyu yüzlü kabın } \\
\text { dışında ağzın hemen altında bir sıra ip baskı bezeme görülür. } \\
\text { İyi pişmiş kabın hamuru kireç, gümüș mika ve taş katkılıdır. }\end{array}$} \\
\hline $\begin{array}{l}\text { Referans-Dönem } \\
\text { (MÖ 13.-11. yüzy1l) }\end{array}$ & \multicolumn{7}{|c|}{$\begin{array}{l}\text { Dupro 1983, Pl.13, No.75, (Niveau V); Bittel - Naumann - } \\
\text { Otto 1941, Abb. 70 8a-8b, 10,12,13,15, Abb 71, 2-4 (Bau-B } \\
\text { MÖ 14.-13. yüzyıl); Ergürer 2015, Lev. 18, 153, , Lev. 19, } \\
\text { 156, 161, (MÖ 11.-9. yüzyıl); Bouthillier 2014, Lev. 46, No. } \\
\text { C, D, F, Fig. } 48 \text { (Geç Bronz Çağ1); Güneri 1987, Res. 4, No. } \\
\text { 8-11, 20-22, Res. No.11,13 (Son Bronz Çağ1); Karauğuz } \\
\text { 2005, Lev. 9, 2-4,7-8 (MÖ 2.bin); Bahar - Koçak 2004, çiz. } \\
\text { 34 no.1-4, Çiz. 35, No. 2-3: Bahar 1999, Lev. XL,No. 1-5 } \\
\text { (Erken Demir Çağ) }\end{array}$} \\
\hline
\end{tabular}

\begin{tabular}{|c|c|c|c|c|c|c|c|c|}
\hline \multirow{2}{*}{3} & Buluntu & Mal & Form & Bezeme & Hamur & $\begin{array}{l}\text { Diş } \\
\text { Renk }\end{array}$ & $\begin{array}{l}\text { İç } \\
\text { Renl }\end{array}$ & A.Çap \\
\hline & $\begin{array}{l}\text { 16-17- } \\
\text { 18G/K41/T6/151 }\end{array}$ & İyi & Çanak & İp bask1 & $5 Y 5 / 1$ & $\begin{array}{l}2.5 \mathrm{Y} \\
7 / 2 \\
\end{array}$ & & $\begin{array}{l}45.4 \\
\mathrm{~cm}\end{array}$ \\
\hline \multicolumn{2}{|c|}{ Tanım } & \multicolumn{7}{|c|}{$\begin{array}{l}\text { Yuvarlatılmış kalın dudaklı, iç bükey profilli, düzleştirilmiş } \\
\text { yüzeylidir. Koyu yüzlü kabın dışında ağzın hemen altında bir } \\
\text { sıra ip baskı bezeme görülür. İyi pişmiş kabın hamurunda kireç, } \\
\text { mika, taş ve şamot bulunmaktadır. }\end{array}$} \\
\hline \multicolumn{2}{|c|}{$\begin{array}{l}\text { Referans-Dönem } \\
\text { (MÖ 13.-11. yüzyıl) }\end{array}$} & \multicolumn{7}{|c|}{$\begin{array}{l}\text { Bittel - Naumann - Otto 1941, Abb. } 70 \text { 8a-8b, 10,12,13,15, } \\
\text { Abb 71, 2-4 (Bau-B MÖ 14.-13. yüzy1l); Ergürer 2015, Lev. 18, } \\
\text { 153, Lev. 19, 156, 161, (MÖ 11-9. yüzyıl); Bouthillier 2014, } \\
\text { Lev. 46, No. C, D, F, Fig. } 48 \text { (Geç Bronz Çăg1); Güneri 1987, } \\
\text { Res. 4, No. 8-11, 20-22, Res. No.11,13 (Son Bronz Çağ1); } \\
\text { Karauğuz 2005, Lev. 9, 2-4,7-8 (MÖ 2.bin); Bahar - Koçak } \\
\text { 2004, çiz. } 34 \text { no.1-4, Çiz. 35, No. 2-3 }\end{array}$} \\
\hline \multirow[b]{2}{*}{4} & $\begin{array}{l}\text { GHB Buluntu } \\
\text { No. }\end{array}$ & Mal & Form & Bezeme & Hamur & $\begin{array}{l}\text { Diş } \\
\text { Renk }\end{array}$ & \begin{tabular}{l|l|} 
İç \\
Renk
\end{tabular} & A.Çap \\
\hline & $\begin{array}{lll}19 \mathrm{E} & \mathrm{K} 39 & \mathrm{~T} 1 \\
282 & & \end{array}$ & Kaba & Çanak & İp baskı & $\begin{array}{l}2.5 Y \\
7 / 4\end{array}$ & $\begin{array}{l}2.5 \mathrm{YR} \\
6 / 6\end{array}$ & $\begin{array}{l}\text { 10YR } \\
6 / 6\end{array}$ & $\begin{array}{l}32.2 \\
\mathrm{~cm}\end{array}$ \\
\hline \multicolumn{2}{|c|}{ Tanım } & \multicolumn{7}{|c|}{$\begin{array}{l}\text { İyi pişmiş kabın hamurunda kireç, taş,şamot ve mika } \\
\text { bulunmaktadır. Yuvarlatılmış kalın dudaklı, iç bükey profilli, } \\
\text { düzleştirilmiş yüzeylidir. Kabın dışında ağzın hemen altında iki } \\
\text { sıra ip baskı bezeme görülür. }\end{array}$} \\
\hline \multicolumn{2}{|c|}{ Referans-Dönem } & \multicolumn{7}{|c|}{$\begin{array}{l}\text { Bittel - Naumann - Otto 1941, Abb. } 70 \text { 8a-8b, 10,12,13,15, } \\
\text { Abb 71, 2-4 (Bau-B MÖ 14.-13. yüzy1l); Ergürer 2015, Lev. }\end{array}$} \\
\hline
\end{tabular}




\begin{tabular}{|c|c|}
\hline $\begin{array}{l}\text { (MÖ } \\
\text { yüzy1l) }\end{array}$ & $\begin{array}{l}\text { 18, 153, , Lev. 19, 156, 161, (MÖ 11-9. yüzyıl); Bouthillier } \\
\text { 2014, Lev. 46, No. C, D, F, Fig. } 48 \text { (Geç Bronz Çă̆1); Güneri } \\
\text { 1987, Res. 4, No. 8-11, 20-22, Res. No.11,13 (Son Bronz } \\
\text { Çağı); Karauğuz 2005, Lev. 9, 2-4,7-8 (MÖ 2.bin); Bahar - } \\
\text { Koçak 2004, çiz. } 34 \text { no.1-4, Çiz. 35, No. 2-3: Bahar 1999, Lev. } \\
\text { XL,No. 1-5 (Erken Demir Cağ) }\end{array}$ \\
\hline
\end{tabular}

\begin{tabular}{|c|c|c|c|c|c|c|c|c|}
\hline \multirow{2}{*}{5} & $\begin{array}{l}\text { GHB } \\
\text { Buluntu No. }\end{array}$ & Mal & Form & Bezeme & Hamur & $\begin{array}{l}\text { Diş } \\
\text { Renk }\end{array}$ & $\begin{array}{l}\text { İç } \\
\text { Renk }\end{array}$ & A.Çap \\
\hline & $\begin{array}{l}\text { 9G/K31/T1/ } \\
919\end{array}$ & Kaba & Çanak & & $\begin{array}{l}10 Y R \\
6 / 3\end{array}$ & $\begin{array}{l}7.5 Y R \\
5 / 3\end{array}$ & & $28 \mathrm{~cm}$ \\
\hline \multicolumn{2}{|c|}{ Tanım } & \multicolumn{7}{|c|}{$\begin{array}{l}\text { Yuvarlatılmış kalın dudaklı, iç bükey profilli, düzleştirilmiş } \\
\text { yüzeylidir. Kabıın dışında ağzın hemen altında bir sıra ip baskı } \\
\text { bezeme görülür. Orta pişmiş, kabın hamurunda kireç ve mika } \\
\text { bulunmaktadır. }\end{array}$} \\
\hline & $\begin{array}{l}\text { ferans-Dönem } \\
\text { Ö } \\
\text { zy1l) }\end{array}$ & \multicolumn{7}{|c|}{$\begin{array}{l}\text { Goldman 1956, Kat,384,No.1127 Late Bronze II Pottery.; } \\
\text { Bittel - Naumann - Otto 1941, Abb. 70 8a-8b, 10,12,13,15, } \\
\text { Abb 71, 2-4 (Bau-B MÖ 14.-13. yüzy1l); Ergürer 2015, Lev. } \\
\text { 18, 153, , Lev. 19, 156, 161, (MÖ 11-9. yüzy1l); Bouthillier } \\
\text { 2014, Lev. 46, No. C, D, F, Fig. } 48 \text { (Geç Bronz Çağ1); Güneri } \\
\text { 1987, Res. 4, No. 8-11, 20-22, Res. No.11,13 (Son Bronz } \\
\text { Çağ1); Karauğuz 2005, Lev. 9, 2-4,7-8 (MÖ 2.bin); Bahar - } \\
\text { Koçak 2004, çiz. } 34 \text { no.1-4, Çiz. 35, No. 2-3 }\end{array}$} \\
\hline
\end{tabular}

\begin{tabular}{|c|c|c|c|c|c|c|c|}
\hline Buluntu & Mal & Form & Bezeme & Hamur & $\begin{array}{l}\text { Diş } \\
\text { Renk }\end{array}$ & $\begin{array}{l}\text { İç } \\
\text { Renk }\end{array}$ & A.Çap \\
\hline 17D/K11/T1/693 & İyi & Çanak & İp bask1 & $\begin{array}{l}10 \mathrm{R} \\
6 / 6\end{array}$ & $\begin{array}{l}2.5 \mathrm{YR} \\
6 / 8\end{array}$ & & $27 \mathrm{~cm}$ \\
\hline Tanım & & \multicolumn{6}{|c|}{$\begin{array}{l}\text { Yuvarlatılmış kalın dudaklı, iç bükey profilli, } \\
\text { düzleştirilmiş yüzeylidir. Kabın dışında ağzın hemen } \\
\text { altında iki sıra ip baskı bezeme görülür. İyi pişmiş, kabın } \\
\text { hamurunda kireç, mika ve şamot bulunmaktadır. }\end{array}$} \\
\hline $\begin{array}{l}\text { Referans-Dönem } \\
\text { MÖ 13.-11. yüzy1l }\end{array}$ & & \multicolumn{6}{|c|}{$\begin{array}{l}\text { Dupro 1983, Pl.13, No.80, Niveau V; Bittel - Naumann } \\
\text { - Otto 1941, Abb. 70 8a-8b, 10,12,13,15, Abb 71, 2-4 } \\
\text { (Bau-B MÖ 14.-13. yüzyıl); Ergürer 2015, Lev. 18, 153, } \\
\text {, Lev. 19, 156, 161, (MÖ 11-9. yüzy1); Bouthillier 2014, } \\
\text { Lev. 46, No. C, D, F, Fig. 48 (Geç Bronz Çağı); Güneri } \\
\text { 1987, Res. 4, No. 8-11, 20-22, Res. No.11,13 (Son Bronz } \\
\text { Çağ1); Karauğuz 2005, Lev. 9, 2-4,7-8 (MÖ 2.bin); } \\
\text { Bahar - Koçak 2004, çiz. } 34 \text { no.1-4, Çiz. 35, No. 2-3: } \\
\text { Bahar 1999, Lev. XL,No. 1-5 (Erken Demir Çăg) }\end{array}$} \\
\hline
\end{tabular}




\begin{tabular}{|c|c|c|c|c|c|c|c|c|}
\hline \multirow{2}{*}{7} & $\begin{array}{l}\text { GHB Buluntu } \\
\text { No. }\end{array}$ & Mal & Form & $\begin{array}{l}\text { Bezem } \\
\text { e }\end{array}$ & $\begin{array}{l}\text { Hamu } \\
\mathrm{r}\end{array}$ & $\begin{array}{l}\text { Diş } \\
\text { Ren } \\
\mathrm{k}\end{array}$ & $\begin{array}{l}\text { İç } \\
\text { Ren } \\
\mathrm{k}\end{array}$ & $\begin{array}{l}\text { A.Ça } \\
\text { p }\end{array}$ \\
\hline & $\begin{array}{l}17- \\
18 \mathrm{G} / \mathrm{K} 49 / \mathrm{T} 3 / 5 \\
8\end{array}$ & $\begin{array}{l}\mathrm{Kab} \\
\mathrm{a}\end{array}$ & $\begin{array}{l}\text { Çana } \\
\mathrm{k}\end{array}$ & & $\begin{array}{l}10 \mathrm{YR} \\
4 / 1\end{array}$ & $\begin{array}{l}2.5 Y \\
4 / 1\end{array}$ & & $28 \mathrm{~cm}$ \\
\hline \multicolumn{2}{|c|}{ Tanım } & \multicolumn{7}{|c|}{$\begin{array}{l}\mathrm{T} \text { formlu ağzın hemen altında oluk bezemeli, iç bükey } \\
\text { profilli, dudağı düz tablalıdır. Dış yüzeyi düzleştirilmiş, iç } \\
\text { yüzeyi açkılıdır. Orta pişmiş, hamurunda kireç ve mika } \\
\text { katkı bulunmaktadır. }\end{array}$} \\
\hline \multicolumn{2}{|c|}{$\begin{array}{l}\text { Referans-Dönem } \\
\text { (MÖ } \quad 13 .-11 . \\
\text { yüzyıl) }\end{array}$} & \multicolumn{7}{|c|}{$\begin{array}{l}\text { Henrickson 1994, Fig. 10.2.1, (a) Fig. 10.2.2. (1-m); } \\
\text { Matsumura 2005, Taf. 3, KL 94-M1(Chronheit III 12-13); } \\
\text { Ergürer 2015, Lev. 19, No.154 (MÖ 11-9. Yüzy1l, Tabak v), } \\
\text { Gunter 1991, Fig. 14, No. 287-88 (Orta ve Geç Demir Çağ); } \\
\text { Y1lmaz 2015, Lev. 20, 5,7; Güneri 1988, Res. 6, 5-10 (Geç } \\
\text { Hitit) }\end{array}$} \\
\hline
\end{tabular}

\begin{tabular}{|c|c|c|c|c|c|c|c|c|}
\hline \multirow[t]{2}{*}{8} & $\begin{array}{l}\text { GHB Buluntu } \\
\text { No. }\end{array}$ & $\begin{array}{l}\text { Ma } \\
\text { l }\end{array}$ & Form & $\begin{array}{l}\text { Bezem } \\
\text { e }\end{array}$ & $\begin{array}{l}\text { Hamu } \\
\text { r }\end{array}$ & $\begin{array}{l}\text { Diş } \\
\text { Ren } \\
\mathrm{k}\end{array}$ & $\begin{array}{l}\text { İç } \\
\text { Ren } \\
k\end{array}$ & $\begin{array}{l}\text { A.Ça } \\
\text { p }\end{array}$ \\
\hline & $\begin{array}{l}\text { 20E/K10/T1/66 } \\
0\end{array}$ & İyi & $\begin{array}{l}\text { Çana } \\
\mathrm{k}\end{array}$ & & $\begin{array}{l}10 \mathrm{YR} \\
5 / 2\end{array}$ & $\begin{array}{l}\text { Gley } \\
14 / N\end{array}$ & & $\begin{array}{l}31.2 \\
\mathrm{~cm}\end{array}$ \\
\hline \multicolumn{2}{|c|}{ Tanım } & \multicolumn{7}{|c|}{$\begin{array}{l}\text { T formlu ağzın hemen altında oluk bezemeli, iç bükey } \\
\text { profilli, dudağı düz tablalıdır. Dış yüzeyi düzleştirilmiş, iç } \\
\text { yüzeyi açkılıdır. İyi pişmiş, kabın hamurunda kireç, mika } \\
\text { ve taş bulunmaktadır. }\end{array}$} \\
\hline & $\begin{array}{l}\text { ferans-Dönem } \\
\text { Ö 13.-11. yüzy1l) }\end{array}$ & \multicolumn{7}{|c|}{$\begin{array}{l}\text { Bittel - Nauman - Otto 1941, Abb. 71, No. } 4 \text { (Bau B); } \\
\text { Henrickson 1994, Fig. 10.2.1, (a) Fig. 10.2.2. (1-m) YHSS } \\
8 \text { (Geç Bronz Çağ1; Güneri 1988, Res. 5, No. } 12 \text { (II. Binin } \\
\text { ikinci yarıs1); Bouthiller vd. 2014, Fig. 51, c, Fig. 46, c,f,k, } \\
\text { Fig. } 48 \text { (level III); Ergürer 2015, Lev. 4, No. 27, Lev. 5, } \\
\text { No. 35-37, } 43 \text { (MÖ 11.-9. yüzy1); Y1lmaz 2015, Lev 20, } \\
\text { No. 5, Matsumura 2005, Taf. 3, KL 92-M150, Taf. 3,KL } \\
\text { 94-M107, Taf. 3, KL 96-M58) (Chronheit III12-13). }\end{array}$} \\
\hline
\end{tabular}

\begin{tabular}{|c|c|c|c|c|c|c|c|}
\hline $\begin{array}{l}\text { GHB } \quad \text { Buluntu } \\
\text { No. }\end{array}$ & Mal & Form & Bezeme & Hamur & $\begin{array}{l}\text { Diş } \\
\text { Renk }\end{array}$ & $\begin{array}{l}\text { İç } \\
\text { Renk }\end{array}$ & A.Çap \\
\hline 16G/K44/T2/365 & Kaba & Çanak & & $\begin{array}{l}2.5 \mathrm{Y} \\
5 / 2\end{array}$ & $\begin{array}{l}7.5 \mathrm{YR} \\
6 / 4\end{array}$ & & $32 \mathrm{~cm}$ \\
\hline Tanım & & \multicolumn{6}{|c|}{$\begin{array}{l}\text { T formlu ağzın hemen altında oluk bezemeli, iç bükey } \\
\text { profilli, dudağı düz tablalıdır. Dış yüzeyi düzleştirilmiş, iç } \\
\text { yüzeyi açkılıdır. Orta pişmiş kabın hamurunda mika } \\
\text { bulunur. }\end{array}$} \\
\hline
\end{tabular}




\begin{tabular}{|l|l|}
\hline & Henrickson 1994, Fig. 10.2.1, (a) Fig. 10.2.2. (1-m) YHSS \\
& 8 (Geç Bronz Çağ1; Güneri 1988, Res. 5, No. 12 (II. Binin \\
ikinci yarıs1); Bouthiller vd. 2014, Fig. 51, c, Fig. 46, c,f,k, \\
Referans-Dönem \\
(MÖ 13.-11. yüzy11) & Fig. 48 (level III); Ergürer 2015, Lev. 4, No. 27, Lev. 5, \\
& No. 35-37, 43 (MÖ 11.-9. Yüzy1l ); Y1lmaz 2015, Lev 20, \\
& No. 5, Matsumura 2005, Taf. 3, KL 92-M150, Taf. 3,KL \\
& 94-M107, Taf. 3, KL 96-M58) (Chronheit III12-13). \\
\hline
\end{tabular}

\begin{tabular}{|c|c|c|c|c|c|c|c|c|}
\hline \multirow{2}{*}{$\begin{array}{l}1 \\
0\end{array}$} & $\begin{array}{l}\text { GHB Buluntu } \\
\text { No. }\end{array}$ & Mal & Form & $\begin{array}{l}\text { Bezem } \\
\text { e }\end{array}$ & $\begin{array}{l}\text { Hamu } \\
\mathrm{r}\end{array}$ & $\begin{array}{l}\text { D1ş } \\
\text { Ren } \\
\mathrm{k}\end{array}$ & $\begin{array}{l}\dot{\text { Iç }} \\
\text { Ren } \\
\mathrm{k}\end{array}$ & $\begin{array}{l}\text { A.Ça } \\
\text { p }\end{array}$ \\
\hline & $\begin{array}{l}\text { 17F- } \\
\mathrm{E} / \mathrm{K} 45 / \mathrm{T} 1 / 84 \\
1\end{array}$ & $\begin{array}{l}\text { Kab } \\
\mathrm{a}\end{array}$ & $\begin{array}{l}\text { Çana } \\
\mathrm{k}\end{array}$ & & $\begin{array}{l}10 Y R \\
4 / 3\end{array}$ & $\begin{array}{l}5 Y R \\
5 / 3\end{array}$ & & $32 \mathrm{~cm}$ \\
\hline \multicolumn{2}{|c|}{ Tanım } & \multicolumn{7}{|c|}{$\begin{array}{l}\text { İçe dönük ağızlı, kalınlaştırılmış dudaklı, dış bükey profilli } \\
\text { ağız parçası. Orta pişmiş, kabın hamurunda kireç, mika, } \\
\text { şamot ve taş bulunmaktadır. }\end{array}$} \\
\hline \multicolumn{2}{|c|}{$\begin{array}{l}\text { Referans-Dönem } \\
\text { (MÖ } \quad 13 .-11 . \\
\text { yüzyıl) }\end{array}$} & \multicolumn{7}{|c|}{$\begin{array}{l}\text { Gunter 1991, Lev. 12, 233-234 (Orta ve Geç Bronz Çă̆1); } \\
\text { Güneri 1988, Res. 5-6, No. } 12 \text { (II. binin ikinci yarıs1); } \\
\text { Bouthiller vd. 2014, Fig. 46, c (level III); Ergürer 2015, } \\
\text { Lev. 4, No. } 29 \text { (MÖ 11.-9. Yüzy1l ); Matsumura 2005, Taf. } \\
\text { 4, KL 94-M56, Taf. 4, KL 92-M225, Taf. 4, KL 95-M370) } \\
\text { (Chronheit III12-13). }\end{array}$} \\
\hline
\end{tabular}

\begin{tabular}{|c|c|c|c|c|c|c|c|c|}
\hline \multirow{2}{*}{$\begin{array}{l}1 \\
1\end{array}$} & $\begin{array}{l}\text { GHB Buluntu } \\
\text { No. }\end{array}$ & Mal & Form & $\begin{array}{l}\text { Bezem } \\
\text { e }\end{array}$ & $\begin{array}{l}\text { Hamu } \\
\mathrm{r}\end{array}$ & $\begin{array}{l}\text { D1ş } \\
\text { Renk }\end{array}$ & $\begin{array}{l}\text { İç } \\
\text { Ren } \\
\mathrm{k}\end{array}$ & $\begin{array}{l}\text { A.Ça } \\
\text { p }\end{array}$ \\
\hline & $\begin{array}{l}\text { 19E/K39/T5/28 } \\
1\end{array}$ & $\begin{array}{l}\mathrm{Kab} \\
\mathrm{a}\end{array}$ & $\begin{array}{l}\text { Çana } \\
\mathrm{k}\end{array}$ & & $\begin{array}{l}7.5 \\
\text { YR } \\
4 / 6\end{array}$ & $\begin{array}{l}2.5 \mathrm{Y} \\
\mathrm{R} 6 / 6\end{array}$ & & $\begin{array}{l}47.6 \\
\mathrm{~cm}\end{array}$ \\
\hline \multicolumn{2}{|c|}{ Tanım } & \multicolumn{7}{|c|}{$\begin{array}{l}\text { İçe dönük ağızlı, kalınlaştırılmış dudaklı, dış bükey profilli } \\
\text { ağız parçası. İyi pişmiş, kabın hamurunda kireç, şamot ve } \\
\text { mika bulunmaktadır. }\end{array}$} \\
\hline \multicolumn{2}{|c|}{$\begin{array}{l}\text { Referans-Dönem } \\
\text { (MÖ 13.-11. yüzyıl) }\end{array}$} & \multicolumn{7}{|c|}{$\begin{array}{l}\text { Bouthiller vd. 2014, Fig. 46, c (level III); Ergürer 2016, } \\
\text { Lev. 4, No. } 29 \text { (MÖ 11.-9. Yüzy1l ); Matsumura 2005, Taf. } \\
\text { 4, KL 94-M56, Taf. 4, KL 92-M225, Taf. 4, KL 95-M370) } \\
\text { (Chronheit III12-13); Dupro 1983, Pl.8, No.44,45, Niveau } \\
\text { V. }\end{array}$} \\
\hline
\end{tabular}

\begin{tabular}{|l|ll|l|l|l|l|l|l|l|}
\hline 1 & $\begin{array}{l}\text { GHB } \\
\text { No. }\end{array}$ & Buluntu & $\begin{array}{l}\text { Ma } \\
\text { l }\end{array}$ & Form & $\begin{array}{l}\text { Bezem } \\
\text { e }\end{array}$ & $\begin{array}{l}\text { Hamu } \\
\mathrm{r}\end{array}$ & $\begin{array}{l}\text { Diş } \\
\text { Ren } \\
\mathrm{k}\end{array}$ & $\begin{array}{l}\text { İç } \\
\text { Ren } \\
\mathrm{k}\end{array}$ & $\begin{array}{l}\text { A.Ça } \\
\mathrm{p}\end{array}$ \\
\hline
\end{tabular}




\begin{tabular}{|l|l|l|l|l|l|l|l|}
\hline $\begin{array}{l}\text { 13G/K30/T6/86 } \\
8\end{array}$ & $\begin{array}{l}\text { İyi } \\
\text { Çana }\end{array}$ & & $\begin{array}{l}5 Y \text { 5/1 } \\
10 \\
\text { YR } \\
6 / 4\end{array}$ & $\begin{array}{l}29.2 \\
\mathrm{~cm}\end{array}$ \\
\hline \multirow{2}{*}{ Tanım } & $\begin{array}{l}\text { İçe dönük ağılıl, kalınlaştırılmış dudaklı, dış bükey } \\
\text { profilli, ağıdan kaideye konik bir gövdeye sahiptir. } \\
\text { Kalka kaidelidir. İyi pişmiş, kabın hamurunda kireç, mika } \\
\text { ve taş bulunmaktadır. }\end{array}$ \\
\hline $\begin{array}{l}\text { Referans-Dönem } \\
\text { (MÖ 13.-11. yüzyıl) }\end{array}$ & $\begin{array}{l}\text { Bouthiller vd. 2014, Fig. 46, c (level III); Ergürer 2015, } \\
\text { Lev. 4, No. 29 (MÖ 11.-9. Yüzyıl ); Matsumura 2005, } \\
\text { Taf. 4, KL 94-M56, Taf. 4, KL 92-M225, Taf. 4, KL 95- } \\
\text { M370) (Chronheit III12-13). }\end{array}$ \\
\hline
\end{tabular}




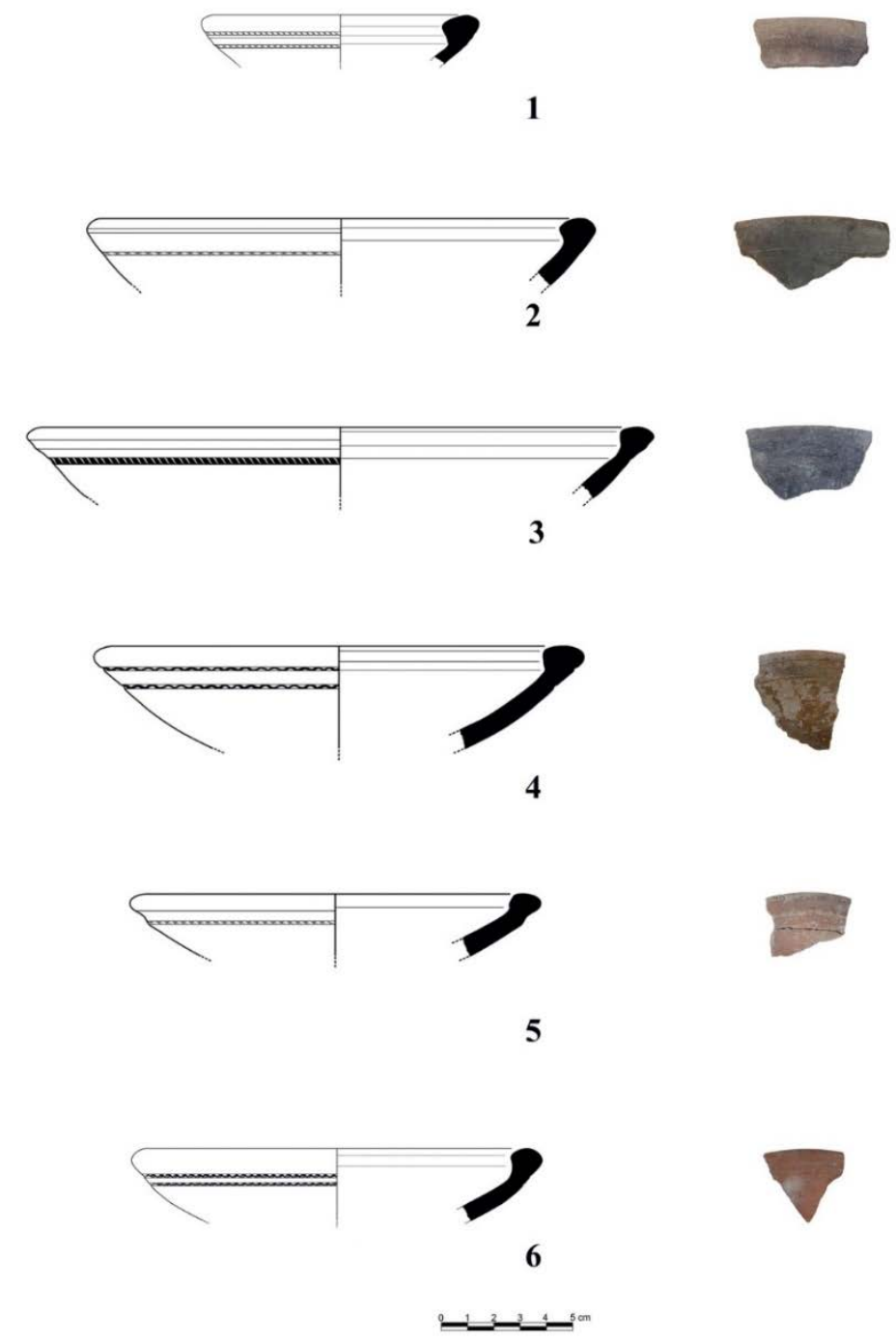




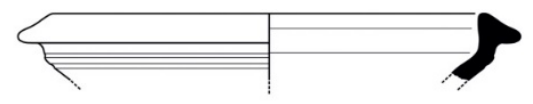

7
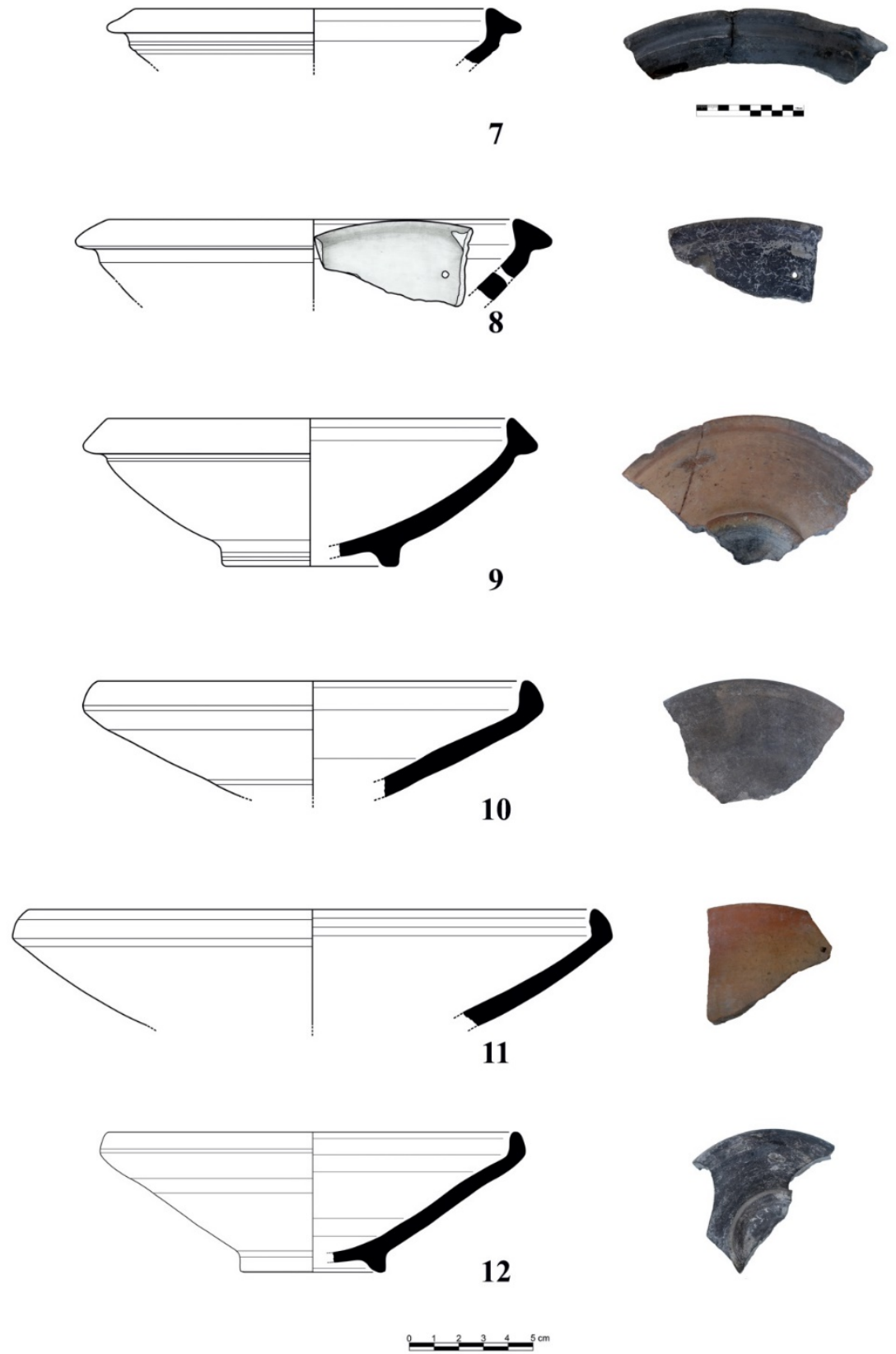


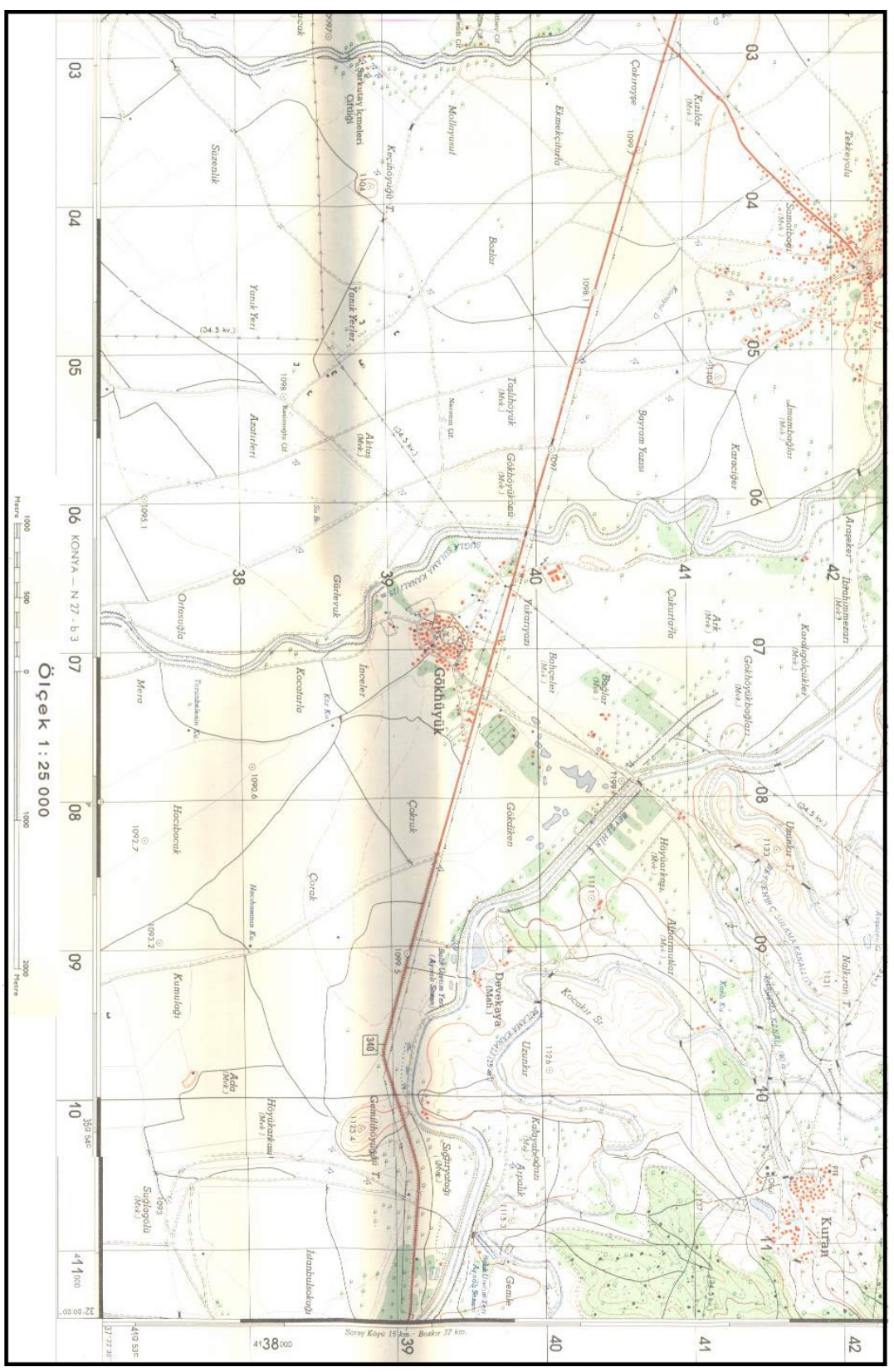


Harita 1: Gökhöyük Bağları Höyüğü’nün Konumunu Gösteren Harita

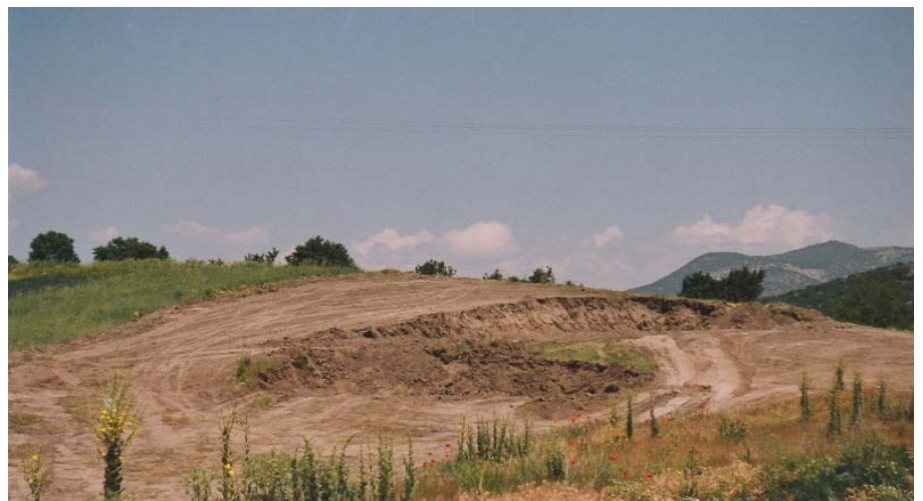

Resim 1: 2002 Yılı Kanal projesi kapsamında Gökhöyük Bağları Höyüğünde yapılan ilk tahribat.

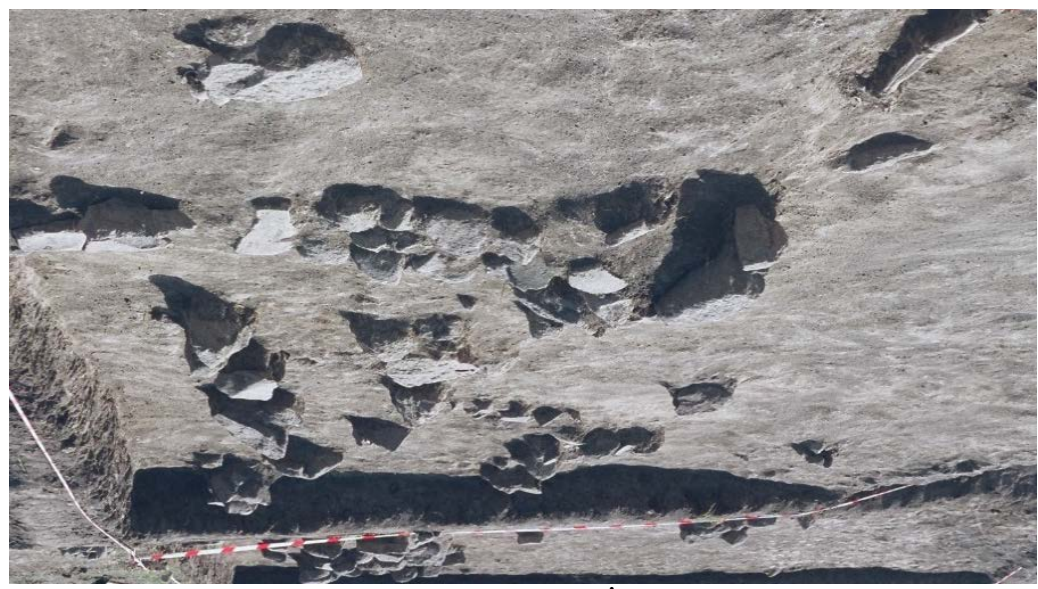

Resim 2: 2002 Y1lı Gökhöyük Bağları Höyüğünde İslamı mezarlar tarafından tahrip edilen Demir Çă̆ Mimari Yapıları. 